\title{
Incomparable Punishments: How Economic Inequality Contributes to the Disparate Impact of Legal Fines and Fees
}

\author{
LINDSAY BING®, BECKY PETTIT, AND ILYA SLAVINSKI
}

Low-level misdemeanor and traffic violations draw tens of millions of people into local courts to pay fines and fees each year, generating billions of dollars in revenue. We examine how standardized legal fines and fees for low-level charges induce disparate treatment and result in disparate impact. Using a mixed-methods approach that incorporates administrative court records as well as interviews with criminal defendants from Texas, we find that although the majority of defendants readily pay for and conclude their case, African American, Latinx, and economically disadvantaged defendants spend disproportionate amounts of money and time resolving theirs. Analysis of criminal case records illustrates the disparate impact of monetary sanctions through the accrual of debt and time spent resolving a charge. Interviews reveal irreconcilable tensions between American ideals of equality in sentencing and the meaning and value of money and time in an increasingly unequal society.

Keywords: monetary sanctions, misdemeanors, criminal legal system, inequality, economic inequality, marketization

Lindsay Bing is a doctoral student in the Department of Sociology at the University of Texas at Austin, United States. Becky Pettit is the Barbara Pierce Bush Regents Professor of Liberal Arts in Sociology at the University of Texas at Austin, United States, where she is also a faculty affiliate of the Population Research Center. llya Slavinski is clinical assistant professor in the Department of Sociology at the University of Buffalo, United States.

(C) 2022 Russell Sage Foundation. Bing, Lindsay, Becky Pettit, and llya Slavinski. 2022. “Incomparable Punishments: How Economic Inequality Contributes to the Disparate Impact of Legal Fines and Fees." RSF: The Russell Sage Foundation Journal of the Social Sciences 8(2): 118-136. DOI: 10.7758/RSF.2022.8.2.06. This research was funded by a grant to the University of Washington from the Laura and John Arnold Foundation (Alexes Harris, PI). We thank the faculty and graduate student collaborators of the Multi-State Study of Monetary Sanctions for their intellectual contributions to the project. We would also like to thank Riad Azar and Taylor Needham for excellent research assistance and members of the Crime, Law, and Deviance workshop at the University of Texas at Austin for helpful comments and suggestions. This research was also supported by grant, P2CHD042849, Population Research Center, awarded to the Population Research Center at The University of Texas at Austin by the Eunice Kennedy Shriver National Institute of Child Health and Human Development. The content is solely the responsibility of the authors and does not necessarily represent the official views of the National Institutes of Health. Direct correspondence to: Lindsay Bing, at Ibing@utexas.edu, Department of Sociology, University of Texas at Austin, United States; Becky Pettit, at bpettit@utexas.edu, Department of Sociology, University of Texas at Austin, United States; and Ilya Slavinski, at ilyaslav@buffalo.edu, Department of Sociology, State University of New York at Buffalo, United States.

Open Access Policy: RSF: The Russell Sage Foundation Journal of the Social Sciences is an open access journal. This article is published under a Creative Commons Attribution-NonCommercial-NoDerivs 3.0 Unported License. 
Monetary sanctions, or the fines and fees levied against criminal defendants, present fundamental challenges to notions of fairness and equal protection. Nearly fifty years ago, the U.S. Supreme Court affirmed equal protection under the law for criminal defendants unable to pay their monetary sanctions, prohibiting the use of imprisonment for unpaid legal financial obligations (LFOs). ${ }^{1}$ Yet, in the decades since, criminal fines and fees have proliferated as consequences for both minor and serious offenses, and the practice of jailing people solely on the basis of outstanding legal debt persists through loopholes in the law (see, for example, Hecht 2017).

Recent scholarship has drawn into focus the damaging consequences that the imposition and collection of monetary sanctions can have on individuals, families, and communities (Harris 2016; Martin et al. 2018; Pattillo and Kirk 2021; Huebner and Giuffre 2022, this volume). A growing corpus of literature, including many articles in this volume, has highlighted the particularly deleterious effects of legal financial obligations among severely disadvantaged groups, such as those living in poverty, people who are unhoused and unstably housed, and those returning from incarceration (Harris, Evans, and Beckett 2011; Beckett and Harris 2011; Cadigan and Kirk 2020; Pattillo and Kirk 2021). Relatively little scholarship, however, has examined the broader impact of fines and fees in the general population.

The imposition of legal fines and fees, especially for low-level misdemeanor charges, is more widespread than any other form of sanction. In Texas alone, approximately 6.7 million fine-only misdemeanor charges are filed each year, equating to one for every five residents in the state (Office of Court Administration 2019). The bulk of these cases, as is true across the United States, are traffic violations or minor, everyday acts of lawbreaking and alleged lawbreaking, that result in a financial penalty. Such widespread, routine use provides new and unique analytical leverage on understanding how monetary sanctions contribute to economic inequality and racial injustice.
Criminal sentencing in the United States, from penalties for serious felonies to the most mundane citations, is characterized by a pursuit of uniformity without regard for social circumstance (Whitman 2003; KantorowiczReznichenko 2018). Formal equality in sentencing, or the principle that two persons convicted for the same crime ought to receive the same punishment, has triumphed over competing notions of equality such as substantive equality, which individualizes punishment according to circumstance and social disadvantage (Whitman 2003; Fredman 2016; Tonry 2018). Over the past fifty years, state and federal penal policies have emphasized mandatory minimum sentences, fixed sentencing grids, and predetermined fine and fee schedules with the express goal of limiting judicial discretion in the name of formal equality. This approach is emblematic of the resurgence of the classical liberal ideals of rule equality, personal responsibility, and an uninhibited market economy, a phenomenon often branded as neoliberalism, guiding American political thought and policy (Soss, Fording, and Schram 2011; Whitman 2003; Sykes et al. 2022, this volume).

The centrality of these principles in American jurisprudence has legitimized uniform sentencing practices in spite of their unequal impact (Tonry 2018; Whitman 2003). Nearly every jurisdiction in the United States sets fine and fee amounts according to offense without regard for differences in ability to pay (Colgan 2017). Despite high and growing levels of wealth and income inequality in the United States (Piketty and Saez 2014), fixed fines are widely accepted as legitimate because they appear equal (Whitman 2003). Excluding a limited number of policy experiments in the 1980s and 1990 s, state and federal courts have resisted instituting any sort of fine system scaled to the income of the defendant (Colgan 2017; Turner and Greene 1999; Winterfield and Hillsman 1993).

The inegalitarian nature of legal fines and fees in the United States stands in contrast to 
the characterization of monetary sanctions in many other countries. European and Latin American countries have long employed a system of sliding scale day fines whereby fine amounts are set relative to the defendant's income as well as the severity of the offense (Kantorowicz-Reznichencko 2018; Colgan 2020). European jurisprudence has considered day fines a superior mechanism to fulfill the principles of equality and deterrence as they equalize the "pain" of punishment (KantorowiczReznichenko 2015; Nagrecha 2020; O’Malley 2009; Whitman 2009).

In this article, we situate an examination of the impact of legal fines and fees in the context of larger patterns of economic inequality. We focus on the case of fine-only, or Class C, misdemeanors, a classification of offenses in Texas encompassing most traffic, public order, city code, and other low-level infractions for which fines are the standard sentence and jail time is not statutorily permissible as punishment. Fine-only misdemeanors are more widely distributed across the population than charges that carry the prospect of jail time, and as such present a unique opportunity to gain leverage on understanding how fines and fees generate and reproduce social inequality.

Economic inequality in the United States has reached historic heights, and economic disadvantage continues to be concentrated among people who are Black, Latinx, or from other historically marginalized groups (Piketty and Saez 2014; Chetty et al. 2020). Exposure to monetary sanctions for low-level misdemeanor charges is widespread, but the burden of debt and financial strain fall along racial, ethnic, and class lines (Pacewicz and Robinson 2020; Stewart et al. 2022, this volume; Huebner and Giuffre 2022, this volume; Pattillo and Kirk 2021). Together, these conditions simultaneously legitimate monetary sanctions and result in disparate impact. The imposition of fixed fines and fees within a racialized political economy deprives greater amounts of money and time from those disadvantaged by other societal institutions like labor and credit markets (Pacewicz and Robinson 2020; Huebner and Giuffre 2022, this volume). Under the veneer of a meritocratic approach to punishment, the American system of monetary sanctions engenders racial injustice.
THEORY AND PREVIOUS LITERATURE Monetary sanctions by their nature sit at the intersection of the court and the market. Scholars have argued that the theory and praxis behind contemporary justice practices are increasingly indistinguishable from that of the market (Pattillo and Kirk 2021; Soss et al. 2011; Wacquant 2009). Revenue generation, rather than public safety alone, motivates aggressive enforcement and collection tactics (Pacewicz and Robinson 2020; Martin 2018; Fernandes et al. 2019; Huebner and Giuffre 2022, this volume). Defendants who are too poor to pay their full sanction up front are put on extended payment plans, or what Mary Pattillo and Gabriela Kirk (2021) term layaway freedom. Courtappointed lawyers, mandated supervision and treatment programs, and even incarceration in some jurisdictions, are frequently pay-for-use services that create revenue streams for public agencies and profit streams for private firms (Page and Soss 2017; Miller 2014; Huebner and Shannon 2022, this volume).

Successful navigation and resolution of contact with the criminal legal system for fine-only charges requires defendants to have access to cash or credit, resources typically acquired through market exchange. In a market economy, income, wealth, and credit are unequally distributed. Yet the criminal legal system sentences defendants under a tariff, or fixed, system of fines and fees, ensuring that the pain of punishment is also unequally distributed. Inequalities in the labor and credit markets, which reflect historic and ongoing racial, ethnic, and other forms of discrimination, are thus replicated in the criminal legal system uniquely through monetary sanctions.

The United States has a long history of racial economic exclusion, whereby people who are Black, Latinx, or members of other marginalized groups are systematically denied access to the same levels of cash and credit afforded to Whites (Pager and Shepard 2008; Dwyer 2018; Krippner 2017). Since the end of Jim Crow and overt legal racial discrimination, racism has become increasingly hidden behind the veil of liberal values such as equality and personal responsibility (Crenshaw 1988; Omi and Winant 1994; Bonilla-Silva 2010; Alexander 2012). Policies and practices that continue to perpet- 
uate existing racial hierarchies are justified through the logic of liberalism, which applies strict rule equality to individuals absent of history, context, or color (Crenshaw 1988; BonillaSilva 2010, 2015).

The criminal legal system is among the social institutions entrenching racial inequality (Wacquant 2009; Soss et al. 2011). The organizations that constitute the criminal legal system, from police to courts, produce racial disparity not necessarily through the racist intent of individual agents, but through the central space they occupy in reifying and legitimizing a racialized social order (Sewell 2016; Ray 2019; Sanchez et al. 2022, this volume). Racial inequality in the criminal legal system, from arrests to felony incarceration and execution, is well documented (Baumgartner, Epp, and Shoub 2018; Weaver et al. 2019; Western 2006; Wakefield and Uggen 2010; Pettit and Western 2004; Eberhardt et al. 2006). The daily, routine activities of criminal justice organizations result in disproportionately disadvantageous outcomes for Black people, legitimizing the unequal allocation of resources across domains by leaving them marked with a negative credential (Pager 2007; Ray 2019). When racialized organizations intersect with other racialized domains, such as the market, racial inequality is amplified and institutionalized.

Labor, housing, and credit markets, the building blocks of uninherited income and wealth, assign different value and risk to groups of individuals, affording them disparate amounts of capital and credit in fundamentally unmeritocratic ways (Krivo and Kaufman 2004; Gaddis 2015; Fourcade and Healy 2013; Krippner 2017). These markets are embedded in a racialized U.S. social structure that has deep historic roots (Crenshaw 2011; Reskin 2012). Although criminal justice contact is stigmatized in these markets, Whiteness is rewarded as a credential, advantaging Whites with better employment prospects (Pager 2007; Quillian et al. 2017; Pedulla and Pager 2019; Gaddis 2015), lower interest rates and higher credit limits (Dwyer 2018; Krippner 2017), and preferential housing choices (Rugh and Massey 2010; Ross and Turner 2005).
The material consequences of racialized market valuations are well documented. Differences in income and wealth between White and non-White Americans have increased since the 1990s (Thompson and Suarez 2015; Piketty and Saez 2014; Chetty et al. 2020). The Black-White wage gap has grown by 20 percent since 2000 , and Black families are estimated to have, on average, just one-tenth the net worth of White families (Hardy and Logan 2020). The Great Recession also resulted in greater relative losses among both Black and Latinx families, contributing to the growing racial wealth divide (McKernan 2013).

In a criminal legal system in which fines are an integral aspect of punishment, market classifications become instrumental in the discipline of defendants. The money and time extracted from defendants depends not only on the severity of the offense, but also on their access to capital and credit. When Black and Latinx defendants have, on average, less access to capital and credit than Whites, monetary sanctions entangle them in the criminal legal system, marking them with a negative credential and further legitimizing their low market value. This feedback loop hides the racially disparate impact of the tariff system of monetary sanctions behind the liberal logic of raceneutral rule equality and personal responsibility (Stewart et al. 2022, this volume; Pattillo and Kirk 2021; Page and Soss 2017).

Table 1 illustrates the disparate punitive extraction demanded from a single traffic ticket, a \$286 stop sign violation, across defendants from four different wage classes. Someone in the top 5 percent of income earners, making $\$ 60$ per hour ( $\$ 120,000$ per year), must submit 4.8 hours of their pretax earnings to the state as punishment for such an offense. Of those who fall in the bottom 30 percent of earners, making \$15 an hour or less, the state demands more than nineteen hours of pretax income. Notably, nearly 50 percent of Black workers earn roughly \$15 an hour or less. ${ }^{2}$ If stop sign violations were randomly distributed across the population, then half of Black defendants, versus fewer than one-third of White defendants, would be charged half a week's wages. 
Table 1. Relative Cost of a $\$ 286.00$ Stop Sign Violation

\begin{tabular}{lcccc}
\hline Income Level & $\begin{array}{c}\text { Hourly Wage } \\
\text { (Pre-Tax) }\end{array}$ & $\begin{array}{c}\text { Labor Hours } \\
\text { Needed to } \\
\text { Pay Ticket }\end{array}$ & $\begin{array}{c}\text { Percent of } \\
\text { All Workers at or } \\
\text { Below Wage }\end{array}$ & $\begin{array}{c}\text { Percent of Black } \\
\text { Workers at or } \\
\text { Below Wage }\end{array}$ \\
\hline High Income & $\$ 60.00$ & 4.8 hours & 95 percent & $>95$ percent \\
Moderate Income & $\$ 25.00$ & 11.4 hours & 60 percent & 80 percent \\
Low Income & $\$ 15.00$ & 19.1 hours & 30 percent & 50 percent \\
Minimum Wage & $\$ 10.00-\$ 7.25$ & $28.6-39.4$ hours & 10 percent & 20 percent \\
\hline
\end{tabular}

Source: Authors' tabulation based on Current Population Survey microdata (Gould 2020).

Notes: Hourly wage distribution for all workers ages sixteen and older. Wages rounded for ease of interpretation.

In this article, we draw attention to how monetary sanctions, especially for low-level misdemeanors, contribute to inequality by exacting proportionately greater money and time from already disadvantaged groups. Reliance on fixed fine and fee structures simply disadvantages people who have fewer resources with which to pay them. Existing patterns of racialized inequality in labor and credit markets mean that Black and Latinx defendants are likely to have less income and wealth to satisfy the courts.

\section{DATA, MEASURES, AND METHODS}

To investigate how monetary sanctions contribute to racially disparate impacts, we use a mixed-methods approach that incorporates administrative court records as well as in-depth interviews with criminal legal defendants from the state of Texas.

\section{DATA}

For our data, we rely on administrative court records that detail exposure to and consequences of fine-only misdemeanors in order to establish patterns of time and resource extraction across racial and ethnic groups. We then draw on data from in-depth interviews with sixty-two people assessed legal financial obligations in order to better understand the lived experiences of those who had the means to pay and those who did not. As part of the Multi-
State Study of Monetary Sanctions, detailed in the introduction to this volume (Harris, Pattillo, and Sykes 2022), we identified three key geographic areas in Texas for our study. Each represents a large, diverse metropolitan area; one is located in southeast Texas (County 1), one in central Texas (County 2), and one is in west Texas (County 3).

We obtained administrative court records through public information requests and automated downloads from publicly accessible online court record systems. Data collection lasted from roughly 2016 to 2018 . We include data from the principal city in each county as well as records from one additional municipality and all justice of the peace courts in Texas County 1 , two additional municipalities in Texas County 2, and a sample of justice of the peace courts in Texas County 3. In total, the harmonized data file contains over 8.9 million Class C misdemeanor charges filed from 2010 to $2018 .^{3}$

We also draw on data from sixty-two interviews with people involved with the criminal legal system as defendants in the same three counties. Our global recruitment strategy, interview methods, and transcript processing followed the protocols of the Multi-State Study. Our local research team recruited participants by reaching out to reentry organizations, posting flyers in high traffic public spaces near criminal courts, and engaging po-

3. Start and end dates of case coverage vary across jurisdiction depending on when the data was acquired. 
Table 2. Qualitative Interview Participant Characteristics

\begin{tabular}{lrr}
\hline & $n$ & Percent \\
\hline Race & 22 & 36 \\
White & 24 & 39 \\
Black & 16 & 25 \\
Other & & \\
Ethnicity & 21 & 33 \\
Hispanic or Latino & 41 & 67 \\
Non-Hispanic or Latino & & \\
Gender identity & & \\
male & 42 & 68 \\
female & 19 & 31 \\
Other & 1 & 2 \\
Age & & \\
18-29 & & \\
$30-39$ & 31 & 49 \\
$40-49$ & 16 & 26 \\
$50-59$ & 9 & 15 \\
$60+$ & 5 & 8 \\
\hline
\end{tabular}

Source: Authors' tabulation.

tential respondents outside courthouses and payment centers. These methods led us to interviews primarily with respondents who were currently justice involved for misdemeanoronly encounters. Although several respondents had extensive histories with the criminal legal system, approximately 40 percent were justice involved for charges that began with a traffic citation or other low-level misdemeanor. Of the sixty-two respondents, twentyseven had never been convicted of a criminal offense yet were assessed legal financial obligations for pretrial supervision, deferred disposition, or a plea agreement that otherwise led to a dismissal.

Interviewees reflect some of the diversity of people assessed legal fines and fees. Table 2 summarizes the personal characteristics of all sixty-two. Just over one-third (36 percent) selfidentified as White and 39 percent as Black. One-third (33 percent) indicated Hispanic or Latinx ethnicity. Two-thirds were men, and nearly half ( 49 percent) were younger than thirty. Although young men of color are overrepresented relative to the general population, low-level misdemeanors reach into a broad and diverse demographic. The interviewees were drawn from many walks of life although they were disproportionately low income, a reflection of the recruitment strategy focused on those visibly involved in the criminal legal system.

\section{MEASURES}

The administrative court records contained charge-level variables detailing demographic, charge, and fine and fee data used to construct our key measures. Table 3 shows descriptive statistics for the final sample.

\section{Dependent Variables}

To gain purchase on how low-level misdemeanor fines and fees produce inequality, we focus our quantitative analyses on the money and time extracted from defendants. We construct a series of dependent variables measuring the assessment, payment, and debt from fines and fees, and the time it takes from case filing to disposition.

We create four dependent variables measuring the monetary penalties defendants faced. In most of the data files, fines and fees were combined into a single category. Restitution was not available in any data files. Fine and fee data was missing for a large proportion of cases from justice of the peace courts in County 3 , so although we include this jurisdiction in descriptive analyses, it is excluded from regression estimates. For the first dependent variable, we create a binary variable indicating whether any LFOs were assessed. As table 3 shows, a financial penalty was assessed in 68 percent of all charges. We then use the combined fine and fee data to create variables for total dollar amount assessed, paid, and still outstanding at the time of data collection among only those charges assessed an LFO.

As table 3 shows, the average amount assessed across all charges assessed fines and fees is close to $\$ 200$. Because the amount paid and outstanding balance are dynamic measures that change as defendants make payments, they cannot be analyzed without accounting for the age of each charge relative to the date when data was collected. We account for this bias by creating a measure for the age of each charge, in days, relative to the last ob- 
Table 3. Descriptive Statistics for Sample

\begin{tabular}{|c|c|c|c|}
\hline Variables & Mean & SD & Median \\
\hline \multicolumn{4}{|l|}{ Race-ethnicity } \\
\hline Black & .28 & & \\
\hline White & .38 & & \\
\hline Latinx & .27 & & \\
\hline Other & .06 & & \\
\hline Female & .33 & & \\
\hline Age & 34.5 & 13 & 31 \\
\hline Median income by zip code & $61,823.4$ & 27,002 & 55,367 \\
\hline \multicolumn{4}{|l|}{ Charge type } \\
\hline Traffic & .88 & & \\
\hline Criminal & .06 & & \\
\hline Other & .06 & & \\
\hline Case duration in days & 183.81 & 290.1 & 89 \\
\hline \multicolumn{4}{|l|}{ Cases disposed within } \\
\hline Three months & .44 & & \\
\hline Six months & .63 & & \\
\hline One year & .78 & & \\
\hline Proportion assessed fine or fee & 68 & & \\
\hline Amount assessed & 199.4 & 139.2 & 180 \\
\hline Paid at ninety days & 114.1 & 124.7 & 0 \\
\hline Balance at ninety days & 67.8 & 137.9 & 134 \\
\hline Observations (n) & & $8,921,311$ & \\
\hline
\end{tabular}

Source: Authors' tabulation.

Notes: Case disposal rates estimated among cases filed 90,180 , and 365 days prior to the date of data acquisition. Balance at ninety days and paid at ninety days include cases filed 75 to 105 days before data was acquired $(n=77,306)$. Total assessed measured among those assessed nonzero amounts in fines and fees $(n=5,931,664)$.

served filing date in each court file. We then use charge age to subset the data to estimate amount paid and balance due during various points in relative time. Table 3 shows mean payment (\$114) and balance (\$68) amounts among charges filed an average of ninety days prior to data collection $(n=77,306)$.

Time is measured in two ways. First, we estimate the proportion of charges, filed within a given period, disposed within three, six, and twelve months of being filed. This strategy provides a measure of case length unbiased by censoring that may occur from the varying dates when the data were collected. Table 3 shows that 44 percent of charges are disposed within ninety days of being filed. By the one-year mark, that figure grows to 78 percent. We also measure time as the number of days between the charge filing date and the disposition date, analyzing a subset of the sample where necessary to reduce censoring bias. As shown in table 3, the median time from filing to disposition is eighty-nine days, a number consistent with the proportion of cases disposed within ninety days. The mean duration of 183.8 days reflects the lengthy tail of the distribution, driven by cases that remain undisposed for years. Both measures, however, are conservative estimates of how long defendants are involved with the courts, given that many defendants continue making payments long after their case is disposed. 


\section{Independent Variables}

We construct a set of independent and control variables to gain purchase on the disparate impacts of monetary sanctions. Race and ethnicity were reported in a single, mutually exclusive variable for all data files and collected by a variety of methods including self-report and citing officer observation. In a few observations, race varied within person. Race was imputed in these observations using modal race of the individual. The combined sample suggested a severe undercount of Latinx defendants relative to their share of the population in sampled counties. In one data source, only 0.01 percent of defendants were identified as Latinx despite making up more than 40 percent of the county population. To account for this likely source of bias, we imputed Latinx ethnicity using defendant surname. ${ }^{4}$ After imputation, 3.9 percent of charges remained coded as missing, Other, or multiracial. These observations were combined with Native American ( $\mathrm{n}=8,416)$, Middle Eastern ( $n=29,979)$, and Asian ( $n=163,553)$ race categories. Table 3 shows that the sample is 38 percent White, 28 percent Black, 27 percent Latinx, and 6 percent Other.

Sex was included in the case records as male or female, and missing in fewer than 2 percent of all charges. Table 3 shows that 33 percent of the sample is female. Sex was imputed within person in cases where individual person identifiers were available. All other observations missing sex were dropped. Within-person sex varied for 2,050 individuals. We left these observations unchanged. Age was available in all but the two largest data sources, we therefore include age in our summary statistics to illustrate the distributional trends of Class C misdemeanors, but do not use it as a covariate in subsequent analyses.

The median household income of a defendant's residential zip code was used as a proxy for socioeconomic status. Income data come from the 2019 American Community Survey 5 -year estimates, which includes median estimated household income at the Zip Code Tabulation Area geographic level (Census Bureau 2019). Residential zip code was available for 93 percent of observations. In some cases ( $\mathrm{n}=106,370)$, defendants were noted as unhoused, transient, living in shelters or other temporary and transitional housing, or in detention facilities. In these cases, median income was manually set roughly equal to the federal poverty line $(\$ 12,500)$. For all others who were missing a residential zip code $(n=285,195$ or 3.2 percent), median income was imputed using race and county. Table 3 shows the average median income of defendants' zip codes, in 2019 dollars, as $\$ 61,823$.

Offense descriptions were coded into three broad categories: traffic, criminal, and Other. Table 3 shows that roughly 88 percent of Class $\mathrm{C}$ misdemeanors are for traffic-related charges. Just 6 percent of charges were criminal, meaning they were classified in the penal code, and 6 percent were coded as Other. The Other category includes an array of relatively uncommon offenses such as violations of the parks and wildlife, health and safety, and elections codes, as well as city ordinances. All cities included in the sample are governed under Home Rule, meaning they can enact city ordinances, punishable as Class C misdemeanors, independently from the state legislature.

\section{METHODS}

We analyze the administrative data using descriptive statistics and fixed-effects linear and logistic regression models to understand how the tariff system of monetary sanctions may produce disparate impacts along race and class lines. In all regression models, filing year and court jurisdiction fixed effects are included to account for variation occurring over time within counties, such as changes in court staff

\footnotetext{
4. Surname ethnicity was estimated using all available criminal court data files from the counties of interest, including data from the Texas Department of Public Safety Computerized Criminal History database of Class $A$ and $B$ misdemeanors and felonies, and estimates were checked against data from the 2010 decennial census. Defendants were coded as Latinx if their surname was identified as such in 80 percent of at least one hundred charges, and their original recorded race was listed as White, missing, or other ( $n=955,700$ charges). Those identified as Asian or Black whose surnames indicated Latinx origin were left with their original racial category; this applied to 2,852 and 13,214 observations, respectively.
} 
or city ordinances. We also cluster robust standard errors by court jurisdiction to account for the clustered nature of the data because cases heard within the same court are not necessarily independent of one another. In addition to race, all models include controls for sex, offense type, a log-transformed measure of median income by zip code, and age of the charge relative to data collection (days). The reference category for race is White. Traffic is the reference for offense type. Additional controls are noted when included. Each model uses as many observations from the sample as is possible to produce unbiased estimates.

For the qualitative interview data, we followed a standardized interview protocol although the exact ordering and wording of questions varied to allow interviewers to follow up on specific answers and to allow respondents to elaborate on their lived experiences. Interviews began with a brief introduction to the study and questions about what brought the respondent to the interview. General topics included education and employment; housing, living arrangements, and family life; politics, health care, and personal characteristics. More specific topics included experiences with the criminal legal system, experiences with legal financial obligations including experiences with payment or the court system, perceptions of implications of having legal debt, and perceptions about system legitimacy.

We used a grounded theory approach to identify key topics in the interviews and wrote thematic memos. We began by reading the interviews, identifying preliminary themes associated with codes and supplemented by word searches for key words, and then rereading the interview transcripts for relevance to each theme. We began by focusing on codes including payment and consequences of nonpayment; issues related to finances, housing, transportation, and employment; and fairness. In examining these codes, we identify three key themes in relation to the complexities involved in resolving low-level misdemeanor charges. These include making difficult choices between payment and other priorities, lack of knowledge and confusion about alternatives to payment, and inability to complete alternatives when available.

\section{RESULTS}

Widespread exposure to and differential consequences of monetary sanctions pose fundamental contradictions to notions of equal justice. Data from more than 8.9 million criminal cases in Texas show that the majority of defendants charged with low-level misdemeanors readily pay monetary sanctions and, as a result, conclude their case. At the same time, unpaid monetary sanctions contribute undue burden disproportionately for African American and Latinx criminal legal defendants and those living in economically disadvantaged areas. Unpaid monetary sanctions expose African American and Latinx defendants to disproportionate punishment and subject them to heightened surveillance.

Fine-only misdemeanors present only a minor inconvenience for White and monied defendants, but for those who are Black or economically disadvantaged, these common infractions can drag on for months. Table 4 shows summary statistics by race and ethnicity. The median income for White defendants' residential zip codes is roughly $\$ 14,000$ higher than that of both Black and Latinx defendants. Black defendants spend between one and two additional months involved with the court before a disposition is entered (218 days versus 159 days for White and 188 days for Latinx defendants). The disparity in time to disposition is also shown in the proportion of charges disposed within three, six, and twelve months of filing. Notably, variance in the proportion of charges that result in financial penalty is less than 3 percentage points, indicating that disparities in the assessment of fines and fees may not be driving unequal outcomes. Among those who were assessed a financial penalty, Black defendants are assessed higher total amounts than either White or Latinx defendants. Black and Latinx defendants also carry a higher balance and have paid less than White defendants at the ninety-day mark.

We analyze these data using multivariable linear and logistic regression methods to better understand whether and how race and ethnicity relate to length of court involvement, the sentencing of fines and fees, and the amount paid and still outstanding at different intervals. Table 5 shows results from a fixed-effects 
Table 4. Descriptive Statistics for Class C Misdemeanors, by Race

\begin{tabular}{lcccc}
\hline & Black & White & Latinx & Other \\
\hline Female & 0.36 & 0.32 & 0.31 & 0.31 \\
Age & 35.9 & 36.1 & 32.6 & 34.7 \\
& $(13.2)$ & $(13.5)$ & $(12.3)$ & $(12.9)$ \\
Median income by zip code & 55221.2 & 69607.1 & 56019.8 & 70226.5 \\
& $(22,839.2)$ & $(30,100)$ & $(21,818.9)$ & $(30,513.1)$ \\
Charge type & & & & \\
$\quad$ Traffic & 0.86 & 0.88 & 0.88 & 0.84 \\
Criminal & 0.08 & 0.06 & 0.05 & 0.03 \\
Other & 0.06 & 0.05 & 0.07 & 0.12 \\
Case duration in days & 218.7 & 159.6 & 188.6 & 154.2 \\
& $(332.4)$ & $(254.6)$ & $(297)$ & $(236.8)$ \\
Case disposed within & & & & \\
Three months & 0.43 & 0.46 & 0.43 & 0.44 \\
Six months & 0.59 & 0.67 & 0.60 & 0.67 \\
One year & 0.74 & 0.82 & 0.76 & 0.82 \\
Proportion charged fine or fee & 0.66 & 0.69 & 0.67 & 0.69 \\
Amount assessed & 216.7 & 191.6 & 196.8 & 182.3 \\
Paid at ninety days & $(148.7)$ & $(126.9)$ & $(143.6)$ & $(143.1)$ \\
Balance at ninety days & 86.4 & 132.4 & 113.1 & 126.2 \\
& $(124.1)$ & $(119.1)$ & $(127.5)$ & $(126.7)$ \\
Observations (n) & 97.3 & 48.6 & 70.1 & 47.4 \\
\hline Source: Authors tabulation & $(156.4)$ & $(119.5)$ & $(139.8)$ & $(125)$ \\
& $2,533,106$ & $3,397,204$ & $2,452,412$ & 538,589 \\
\hline & & & &
\end{tabular}

Source: Authors' tabulation.

Notes: Case disposal rates estimated among cases filed 90,180, and 365 days prior to the date of data acquisition. Amount paid and balance due at ninety days estimated among all charges filed an average of ninety days prior to data acquisition.

logistic regression model estimating the odds of being assessed any fines and fees for a fineonly misdemeanor in our sample. The difference in the odds of being charged financial penalties between Black and White defendants was scant, but that between White and Latinx defendants substantial. Latinx defendants had roughly 25 percent lower odds of being assessed fines or fees. Race does not appear a significant determinant of whether fines and fees are assessed, consistent with our argument that disparate treatment is not the sole driver of racial inequality. Ethnicity, however, does appear to be related to the application of fines and fees. Table 6 digs deeper, showing results from three fixed-effects linear regres- sion models estimating the amounts assessed, paid, and still due.

Table 6 shows the results from fixed-effects linear regression models. Model 2 shows estimates for the total amount assessed, in fines and fees, among all charges where LFOs were applied. Results show no significant differences between the dollar amounts assessed between Black, White, and Latinx defendants. Although criminal and other (city ordinance, failure to appear, and so on) charges do appear to come with significantly higher fines and fees than traffic charges, it would not appear that racially biased assessments of fines and fees drive disparate outcomes. Instead, as estimates from model 3 and model 4 reveal, 
Table 5. Fixed-Effects Logistic Regression of Being Assessed LFOs

\begin{tabular}{|c|c|c|c|}
\hline & $\begin{array}{l}\text { Model } 1 \\
\text { Odds Ratio }\end{array}$ & & $\begin{array}{c}\text { Model } 1 \\
\text { Odds Ratio }\end{array}$ \\
\hline Black & $\begin{array}{c}0.96 \\
(0.05)\end{array}$ & Other charge (vs. traffic) & $\begin{array}{l}0.56^{* *} \\
(0.12)\end{array}$ \\
\hline Latinx & $\begin{array}{l}0.75^{* * *} \\
(0.04)\end{array}$ & $\begin{array}{l}\text { Median income by zip code } \\
\text { (logged) }\end{array}$ & $\begin{array}{l}1.36^{* *} \\
(0.13)\end{array}$ \\
\hline Other or unknown & $\begin{array}{c}0.88 \\
(0.06)\end{array}$ & Constant & $\begin{array}{c}0.08^{*} \\
(0.08)\end{array}$ \\
\hline Female & $\begin{array}{l}1.13^{* * *} \\
(0.04)\end{array}$ & Observations & $8,759,398$ \\
\hline Criminal charge (vs. traffic) & $\begin{array}{l}0.47^{* * *} \\
(0.04)\end{array}$ & Pseudo $\mathrm{R}^{2}$ & .08 \\
\hline
\end{tabular}

Source: Authors' tabulation.

Notes: Year and data source (court) fixed effects included, robust standard errors clustered by data source in parentheses. Controls for age of case included but not shown.

${ }^{* * *} p<.001,{ }^{* *} p<.01,{ }^{*} p<.05$

Black and Latinx defendants have a substantially harder time paying off their fines and fees than White defendants. Models 3 and 4 are both estimated among a subset of charges that includes those assessed any fines and fees whose charges are between seventy-five and 105 days old (measured from filing date to date of data collection). As shown by model 3, after ninety days, Black defendants have paid $\$ 42$ less and Latinx defendants have paid \$8.6 less than White defendants, significant at the $p<.001$ and $p<.01$ levels, respectively. Model 4 estimates for outstanding balance at ninety days tell a similar story. Black defendants owe, on average, $\$ 68$ more than White defendants ninety days after their case was filed; Latinx defendants owe roughly \$19 more. Despite evidence supporting the claim that monetary sanctions are applied in a racially neutral fashion, models 3 and 4 provide robust evidence for racially disparate impacts. We next examine the amount of time defendants spend resolving their case.

Table 7 shows the number of days from citation filing to disposition across Class $\mathrm{C}$ misdemeanors filed at least one year prior to the date of data acquisition ( $\mathrm{n}=7,028,884)$. The data is subset in this model to reduce censoring bias. Year and jurisdiction (court) fixed effects are included in the model. Robust standard errors, presented in parentheses, are clustered by juris- diction. African Americans can expect to spend, on average, an additional fifty-four days involved with the courts for a Class $\mathrm{C}$ misdemeanor and Latinx defendants will spend an additional twenty-three days relative to White defendants. The type of offense was not a significant predictor of length of court involvement. However, median income by zip code was significant. Estimates show that defendants from wealthier zip codes can expect a quicker resolution than those from poorer neighborhoods.

Results from these administrative data reveal stark differences in the amount of time extracted and debt accrued across race in cases of low-level violations. Black and Latinx defendants are consistently involved with the court system for longer than White defendants, and hold more debt for comparable offenses. White defendants appear to navigate low-level misdemeanors with relative ease, concluding their cases and paying off their debt sooner than others. These findings support our argument that the tariff system of monetary sanctions amplifies racial inequality across domains.

\section{INSIGHTS FROM INTERVIEWS}

Interviews with defendants reveal irreconcilable tensions between American ideals of formal equality in criminal sentencing and the value and meaning of money in an increasingly unequal society. Access to capital and credit 
Table 6. Fixed-Effects Linear Regression Models at 90 days.

\begin{tabular}{lccc}
\hline & Model 2 & Model 3 & Model 4 \\
& Amount Assessed & Baid & Balance \\
\hline Black & 20.69 & $-42.22^{* * *}$ & $68.17^{* * *}$ \\
Latinx & $(14.75)$ & $(7.80)$ & $(9.48)$ \\
& 15.32 & $-8.66^{* *}$ & $18.94^{* *}$ \\
Other or uknown & $(9.69)$ & $(2.25)$ & $(5.40)$ \\
Female & $-4.37^{* *}$ & 2.11 & 3.79 \\
Criminal charge (vs. traffic) & $(1.16)$ & $(2.03)$ & $(4.40)$ \\
Other charge (vs. traffic) & $-5.51^{* *}$ & -0.12 & 0.79 \\
& $(1.44)$ & $(2.28)$ & $(2.39)$ \\
Median income by zip code (logged) & $90.73^{* *}$ & -20.89 & $91.47^{* * *}$ \\
Constant & $(17.97)$ & $(10.38)$ & $(16.12)$ \\
Observations & $43.84^{*}$ & -5.35 & $72.85^{* * *}$ \\
\hline
\end{tabular}

Source: Authors' tabulation.

Notes: Year and data source (court) fixed effects included, robust standard errors clustered by data source in parentheses. Model 2 estimated among cases charged any LFOs. Models 3 and 4 estimated among charges assessed LFOs, and filed 75 to 105 days prior to data collection. Controls for age of charge included but not shown.

${ }^{* * *} p<.001,{ }^{* *} p<.01,{ }^{*} p<.05$

Table 7. Fixed-Effects Linear Regression of Duration of Case, in Days

\begin{tabular}{|c|c|c|c|}
\hline & $\begin{array}{c}\text { Coefficient } \\
\text { (Standard } \\
\text { Error) }\end{array}$ & & $\begin{array}{c}\text { Coefficient } \\
\text { (Standard } \\
\text { Error) }\end{array}$ \\
\hline Black & $\begin{array}{c}54.51^{*} \\
(17.56)\end{array}$ & Other charge (vs. traffic) & $\begin{array}{c}29.85 \\
(15.73)\end{array}$ \\
\hline Latinx & $\begin{array}{l}23.22^{* *} \\
(6.46)\end{array}$ & $\begin{array}{l}\text { Median income by zip code } \\
\text { (logged) }\end{array}$ & $\begin{array}{l}-26.82^{*} \\
(11.09)\end{array}$ \\
\hline Other/UK & $\begin{array}{l}-6.76^{*} \\
(2.66)\end{array}$ & Constant & $\begin{array}{l}202.09^{* * *} \\
(33.60)\end{array}$ \\
\hline Female & $\begin{array}{l}3.78 \\
(2.30)\end{array}$ & $\begin{array}{l}\text { Observations } \\
\mathrm{R}^{2}\end{array}$ & $\begin{array}{c}7,028,884 \\
013\end{array}$ \\
\hline Criminal charge (vs. traffic) & $\begin{array}{l}-23.52 \\
(29.65)\end{array}$ & $\mathrm{R}^{2}$ & \\
\hline
\end{tabular}

Source: Authors' tabulation.

Notes: Year and data source (court) fixed effects included, robust standard errors clustered by data source in parentheses. Sample limited to disposed cases filed at least one year prior to the last observation in the data. Controls for age of case included but not shown.

${ }^{* *} p<.001,{ }^{* *} p<.01,{ }^{*} p<.05$ 
shape the process, punishment, and consequences of fine-only misdemeanors, resulting in a two-tiered system of justice. In line with the insights from Beth Huebner and Andrea Giuffre (2022, this volume), defendants characterized the fine-only misdemeanor process as onerous, administratively opaque, and excessively punitive. We observed marked differences in the reflected experiences of defendants as they attempted to resolve their fine-only misdemeanor charges. For those with financial resources, low-level misdemeanors are simply an inconvenience. For those with little cash and credit, however, they mean mounting debt and sometimes years long entanglement with the system.

Defendants with access to cash and credit, whether through earned income or support from family, report little trouble resolving minor charges. For example, Julian, a young Latino man, has had several run-ins with the criminal legal system. At the time of his interview, he was on probation for possession with intent to distribute marijuana. In spite of these legal troubles, he has had no issues paying for speeding and other traffic tickets. He explained, "Well, with those tickets, they weren't difficult at all. I always hired one of those lawyers that you just give fifty bucks to and then they go to court for you.... It always got settled. Either defensive driving, or it would just be settled by the lawyer. I guess they worked their magic, or whatever." Julian's access to cash, at some times provided by his parents, afforded him the luxury of hiring a traffic court attorney, saving him both the time involved in appearing in court himself, and the addition of a traffic conviction on his driving record.

When wealthier defendants do end up in a long and arduous process for a low-level misdemeanor, it is often by choice. For example, Taylor, a forty-two-year-old White man, became well known in one municipal court for being a well-heeled professional on a mission to get his case dismissed. Taylor was charged with illegal parking in a space reserved for people with disabilities and faced a $\$ 500$ ticket. He believed that he was innocent because the spot was improperly marked. He hired several lawyers, spent thousands of dollars, and made countless court appearances in an attempt to get his case dismissed. He explained his rationale: "it's now not about the money, it's about the principle." Unlike many defendants in this study, Taylor was not drawn into a long court process because of his inability to pay up front. $\mathrm{He}$ fought his case because he had the means to do so, a luxury that many defendants could not afford.

When defendants with fewer financial resources are drawn into lengthy court processes, they often face mounting debt and collateral consequences. For example, Kimberly, a fortyyear-old Black woman, had accrued substantial debt, additional tickets, and surcharges following an unpaid citation for driving without insurance. At the time, she was between jobs and struggling to provide for her family. The unpaid surcharges prevented her from renewing her driver's license, leading to the accumulation of more tickets. She reflected on the stress she experienced as her debt grew: "It has been very stressful and it's been a burden. Because then you have to choose between getting something maybe I really need for my kids and paying this and taking care of it to try to get it cleared and off my back. So it's been really hard. Especially when I wasn't working and didn't (have) resources at the time.... I was just trying to maintain and that's why I kind of put it off for a while 'cause I was just really struggling."

Kimberly, unlike Taylor and Julian, did not have the financial resources to avoid a conviction. Until a legislative change in 2017, traffic convictions in Texas resulted in hefty annual surcharges owed to the Department of Public Safety, the Texas equivalent of the Department of Motor Vehicles. When Kimberly finally had the means to make payments toward her traffic charges, they were entered as convictions, triggering additional financial penalties that wealthier defendants are unlikely to face. As she explained, "So from that particular fine, other fines came. Then it just multiplied and multiplied and multiplied. And then as soon as you pay it off, then there's something else, the conviction was put on there. So it was like the day after I paid something, next day conviction's on there. So then there's more money involved. It's like never ending."

Kimberley's case was far from unique. Despite holding regular employment in various 
state offices, including one at the Department of Public Safety, she had limited access to cash and credit at the time of her ticket. In a similar story, Marie, a twenty-seven-year-old Latina woman with a bachelor's degree in psychology, owed roughly $\$ 1,000$ for two outstanding traffic tickets. Initially, the tickets were for just a few hundred dollars, she told us. She was a fulltime student at the time she was ticketed, which made it impossible for her to pay them off. Unlike wealthier defendants, her family did not have the financial means to help avoid conviction or swiftly pay them off. Since then, her debt with the court grew and warrants were issued for her arrest. Like Kimberley, Marie's limited access to cash and credit led to consequences that extended well beyond the initial violation.

These difficult decisions can also lead people to forgo looking for work or continuing their education. John, a Black man, told us he had to take time off from earning his associate degree to pay off his LFOs. Rather than finishing the degree in two years, it took him five, delaying his entry into a stable career. Tara, a young woman, explains the trade-offs she had to make:

Yeah. It affected me in the long term, because I could have used that money for something else, as far as education or as far as being more stable. I feel like if I wouldn't have had to pay so much money towards them, then I wouldn't have to be repeating my troubles and I wouldn't have to feel like I gotta go another route to get what I need. If I take a whole $\$ 2,000$ check or $\$ 2,000$ refund check and I send it to them, then I have nothing else.... What does that create a person to do? Go out there and commit another crime.

The financial circumstances many defendants described facing when initially charged with low-level misdemeanors suggests that they may have been eligible for indigency waivers or alternative forms of payment, such as community service. However, indigency hearings resulting in fine and fee waivers are extremely rare in Texas fine-only courts, despite multiple legislative changes in recent years aimed at reducing the financial burden placed on impoverished defendants. Data from the Texas Office of Court Administration show that indigency waivers are rarely granted for fineonly misdemeanors, while arrest warrants and satisfying fines and fees through jail time are far more common (Office of Court Administration 2019). At the county level, fewer than 1 percent of misdemeanor cases are granted an indigency waiver, a particularly surprising finding in a state where the poverty rate is well above the national average. At the same time, on average across counties, 8.8 percent of cases are satisfied by jail credit and nearly half ( 47.2 percent) of cases in one county are satisfied by spending time in jail (Slavinski and Pettit 2021).

Many defendants interviewed said they had no idea that indigency waivers or payment alternatives even existed. As true of the municipal court system in Missouri, practices differ from one court to the next, and defendants struggle to find information about their options (Huebner and Giuffre 2022, this volume). Often these options were presented to them only after they had defaulted in payments and accrued substantial debt. The requests of the few who did pursue these options were either flat out denied or the alternatives they were offered felt just as burdensome as the fines and fees.

For example, Remy, a thirty-seven-year-old White woman who was unemployed and living in a small suburb, described imploring the prosecutor to reduce her fines or allow her to do some kind of diversion program. This was her first time involved with the courts, and without the means to pay for the fine, she had hoped the prosecutor would offer her an alternative. The prosecutor did not, nor did he make her aware that she could formally request an ability to pay hearing in front of a judge. Representing herself, like most defendants in Class C misdemeanors, her access to alternatives rested entirely with the prosecutor and judge. She did not have the means to hire anyone to "work their magic," in the words of Julian, the well-off defendant who used traffic lawyers to secure dismissals.

Marie, the young woman who had ended up with $\$ 1,000$ in debt and multiple arrest warrants stemming from traffic tickets she got while in college, eventually did learn that she could pay off her debt with community service hours. 
However, when she asked whether her full-time volunteer service with AmeriCorps qualified to cover the hours, she was told they would not. She had already picked up two extra part-time jobs to supplement the poverty-level stipend she received from AmeriCorps and felt she had no additional time to complete the hours set by the court.

Defendants commonly found the community service option demanding and burdensome. The state minimum requires defendant's debt be reduced by at least $\$ 12.50$ for every hour of community service they are assigned, a rate that extracts substantial time from defendants already facing many challenges. For example, Hunter, a fifty-six-year-old White woman unable to work because of her ongoing battle with breast cancer, was assigned fifty-two hours of community service in lieu of cash payment. She was given ninety days to complete the hours. She was very worried, she said, about being able to finish them on time: "It's gonna be difficult, yes, because from day to day you really don't know how you're gonna feel. Along with the medications you take and doctors and all that, yeah. I'm stage four breast cancer into the bone, but I have to do this otherwise what's my other option?"

Hunter had her doctor write a letter to the court explaining her health condition, but she was doubtful as to whether it helped. The stress she experienced points to how monetary sanctions may negatively affect health, a relationship that Alexes Harris and Tyler Smith explore (2022, in this volume).

As these interviews show, the difficulty that defendants paying off fines and fees experience is not isolated to those living in extreme poverty. Even among defendants who have completed college and are stably employed, their earnings are just not high enough to easily resolve minor traffic tickets. The cost, in terms of both money and time, of routine monetary sanctions extracts substantially more punishment from those with limited means.

\section{DISCUSSION AND CONCLUSION}

Adjusting criminal legal punishment to account for capacity to pay runs counter to dominant ideals of rule equality in American jurisprudence. At the same time, in ignoring how the criminal legal system is embedded in a landscape of growing and racialized economic inequality, American jurisprudence that increasingly relies on monetary sanctions is unjust. The imposition of legal fines and fees deprives more money and time from people simply on the basis of their economic standing. Moreover, and much like historic poll taxes and separate-but-equal education doctrine, legal fines and fees are racialized in their application as well as their impact. Black Americans have, on average, significantly less capital and credit than White Americans. Thus the existing system of monetary sanctions both entrenches and legitimizes racial inequality in both the legal and economic domains (Ray 2019; BonillaSilva 2015).

These findings have both theoretical and methodological implications. Theoretically, they contribute to the growing literature on the marketization of the criminal legal system (Pattillo and Kirk 2021; Miller 2014; Page and Soss 2017; Soss et al. 2011; Wacquant 2009). Analyses reveal how reliance on fixed fines and fees amplify inequality by allowing market classifications to ultimately determine the severity of punishment. In presenting the contemporary regime of monetary sanctions within the broader context of racialized economic inequality, this article shows how seemingly colorblind, equal sentencing produces racially disparate impacts. The results in this article highlight the tension between the meaning of justice and how monetary sanctions are experienced in an era of rising, and racialized, economic inequality.

Methodologically, these findings demonstrate the importance of combining qualitative and quantitative data to better understand how monetary sanctions can be viewed as a legitimate, and even preferred, sentencing option yet simultaneously contribute to racial injustice. Data from court records show that fine-only misdemeanors are distributed more broadly by race, gender, and social class than more serious forms of criminal legal involvement. Consistent with insights from Matthew Menendez and his colleagues (2019), most people who are assessed monetary sanctions pay them within the stipulated time. Moreover, those interviewed who had adequate resources to resolve their 
monetary sanctions neither problematized the punishment nor experienced LFOs as particularly cumbersome.

The negative consequences and thus the pain of monetary sanctions-including outstanding debt, repeat court appearances, and lengthy periods resolving tickets-are concentrated among those too poor to pay but too wealthy for a waiver (Pattillo and Kirk 2021). Disproportionately, these excessive burdens fall on people of color (Stewart et al. 2022, this volume; Sanchez et al. 2022, this volume; Harris, Evans, and Beckett 2011). Indeed, court records show amounts assessed, outstanding balance, and time before disposition are higher for Black and Latinx defendants than for White. Qualitative interview data provide valuable insights into how defendants experience monetary sanctions and the mechanisms that lead to extended surveillance and added costs. People who are unable to pay assessed fines and fees commonly face difficult choices between payment and other priorities. The nature of those choices and the pain of punishment are structured by racialized economic inequality.

Monetary sanctions are a central mechanism of racial inequality in the contemporary criminal legal system. Studies on the inequalityinducing effects of mass incarceration and other forms of criminal justice contact have often had difficulty isolating the effects of criminal legal contact from other, highly correlated, causes of poverty and economic instability. Despite clear and compelling evidence that mass incarceration has been fueled by shifts in policing, prosecution, and sentencing (National Research Council 2014), the correlation between economic disadvantage and criminal surveillance has undermined strong empirical claims of the effects of criminal justice contact. The ubiquity of monetary sanctions, especially for low-level misdemeanor charges, offers a unique opportunity to disentangle the mechanisms that drive entrapment in the criminal justice system from its impact.

Although numerous states have undertaken policy reform aimed at reducing the unequal consequences of economic sanctions, these efforts are likely to fall short of their goals. States, including Texas, continue to treat poverty as an extenuating circumstance rather than a com- mon condition. Both the process and the punishment demand more money and time from those with limited means. Fixed monetary sanctions institutionalize and legitimize racial inequality by overlooking the financial toll that historic and contemporary racism take on Black and Latinx families. Legal sentences mandating economic sanctions are designed by legislatures and doled out by the courts. Yet, in a highly unequal society with differential capacity to pay, the pain of punishment is determined by the markets, not the law. Thus, and despite constitutional prohibitions against unequal punishment on the basis of capacity to pay, monetary sanctions inflict punishments that are unequal by race and ethnicity and promise to become even more so as marketbased economic inequality grows.

\section{REFERENCES}

Alexander, Michelle. 2012. The New Jim Crow. New York: The New Press.

Baumgartner, Frank R., Derek A. Epp, and Kelsey Shoub. 2018. Suspect Citizens: What 20 Million Traffic Stops Tell Us About Policing and Race. Cambridge: Cambridge University Press.

Beckett, Katherine, and Alexes Harris. 2011. “On Cash and Conviction." Criminology \& Public Policy 10(3): 509-37. DOI: https://doi.org/10.1111 /j.1745-9133.2011.00726.x.

Bonilla-Silva, Eduardo. 2010. Racism Without Racists: Color-Blind Racism and the Persistence of Racial Inequality in the United States. Boulder, Colo.: Rowman \& Littlefield.

—. 2015. "The Structure of Racism in ColorBlind, 'Post-Racial' America." American Behavioral Scientist 59(11): 1358-76. DOI: https://doi .org/10.1177/0002764215586826.

Cadigan, Michele, and Gabriela Kirk. 2020. “On Thin Ice: Bureaucratic Processes of Monetary Sanctions and Job Insecurity." RSF: The Russell Sage Foundation Journal of the Social Sciences 6(1): 113-31. DOI: https://doi.org/10.7758/RSF.2020 6.1.05.

Chetty, Raj, Nathaniel Hendren, Maggie R. Jones, and Sonya R. Porter. 2020. “Race and Economic Opportunity in the United States: An Intergenerational Perspective." The Quarterly Journal of Economics 135(2): 711-83. DOI: https://doi.org /10.1093/qje/qjz042. 
Colgan, Beth A. 2017. “Graduating Economic Sanctions According to Ability to Pay." lowa Law Review 103(53): 53-112.

_. 2020. "Beyond Graduation: Economic Sanctions and Structural Reform." Duke Law Journal 69(7): 1529-83.

Crenshaw, Kimberlé Williams. 1988. “Race, Reform, and Retrenchment: Transformation and Legitimation in Antidiscrimination Law." Harvard Law Review 101(7): 1331-87. DOI: https://doi.org/10 $.2307 / 1341398$.

_. 2011. "Twenty Years of Critical Race Theory: Looking Back to Move Forward." Connecticut Law Review 43(5): 1253-353.

Dwyer, Rachel E. 2018. "Credit, Debt, and Inequality." Annual Review of Sociology 44(1): 237-61. DOI: https://doi.org/10.1146/annurev-soc-060116 -053420 .

Eberhardt, Jennifer L., Paul G. Davies, Valerie J. Purdie-Vaughns, and Sheri Lynn Johnson. 2006. “Looking Deathworthy: Perceived Stereotypicality of Black Defendants Predicts Capital-Sentencing Outcomes." Psychological Science 17(5): 383-86. DOI: https://doi.org/10.1111/j.1467-9280.2006 .01716.x.

Fernandes, April D., Michele Cadigan, Frank Edwards, and Alexes Harris. 2019. “Monetary Sanctions: A Review of Revenue Generation, Legal Challenges, and Reform." Annual Review of Law and Social Science 15(1): 397-413. DOI: https:// doi.org/10.1146/annurev-lawsocsci-101518 -042816 .

Fourcade, Marion, and Kieran Healy. 2013. “Classification Situations: Life-Chances in the Neoliberal Era." Accounting, Organizations and Society 38(8): 559-72. DOI: https://doi.org/10.1016/j.aos .2013.11.002.

Fredman, Sandra. 2016. “Substantive Equality Revisited." International Journal of Constitutional Law 14(3): 712-38. DOI: https://doi.org/10.1093/icon /mow043.

Gaddis, S. Michael. 2015. “Discrimination in the Credential Society: An Audit Study of Race and College Selectivity in the Labor Market." Social Forces 93(4): 1451-79. DOI: https://doi.org/10 $.1093 / \mathrm{sf} / \mathrm{sou} 111$.

Gould, Elise. 2020. State of Working America Wages 2019. Washington, DC: Economic Policy Institute. Accessed August 17, 2021. https://www.epi.org /publication/swa-wages-2019.

Hardy, Bradley L., and Trevon D. Logan. 2020. “Ra- cial Economic Inequality Amid the COVID-19 Crisis." Hamilton Project Essay 2020-17. Washington, DC: Brookings Institution. Accessed August 17, 2021. https://www.brookings.edu/research /racial-economic-inequality-amid-the-covid-19 -crisis.

Harris, Alexes. 2016. A Pound of Flesh: Monetary

Sanctions as Punishment for the Poor. New York: Russell Sage Foundation.

Harris, Alexes, Heather Evans, and Katherine Beckett. 2011. "Courtesy Stigma and Monetary Sanctions: Toward a Socio-Cultural Theory of Punishment." American Sociological Review 76(2):

234-64. DOI: https://doi.org/10.1177/000312 2411400054.

Harris, Alexes, Mary Pattillo, and Bryan L. Sykes. 2022. "Studying the System of Monetary Sanctions." RSF: The Russell Sage Foundation Journal of the Social Sciences 8(1): 1-33. DOI: https://doi .org/10.7758/RSF.2022.8.1.01.

Harris, Alexes, and Tyler Smith. 2022. “Monetary Sanctions as Chronic and Acute Health Stressors: The Emotional and Physical Strain of People Who Owe Court Fines and Fees." RSF: The Russell Sage Foundation Journal of the Social Sciences 8(2): 36-56. DOI: https://doi.org/10.7758 /RSF.2022.8.2.02.

Hecht, Nathan L. 2017. The State of the Judiciary in Texas. Austin: The Supreme Court of Texas.

Huebner, Beth M., and Andrea Giuffre. 2022. "Reinforcing the Web of Municipal Courts: Evidence and Implications Post-Ferguson." RSF: The Russell Sage Foundation Journal of the Social Sciences 8(1): 108-27. DOI: https://doi.org/10.7758 /RSF.2022.8.1.05.

Huebner, Beth M., and Sarah K.S. Shannon. 2022. “Private Probation Costs, Compliance, and the Proportionality of Punishment: Evidence from Georgia and Missouri." RSF: The Russell Sage Foundation Journal of the Social Sciences 8(1): 179-99. DOI: https://doi.org/10.7758/RSF 2022.8.1.08.

Kantorowicz-Reznichenko, Elena. 2015. “Day-Fines: Should the Rich Pay More?" Review of Law \& Economics 11(3): 481-501. DOI: https://doi.org /10.1515/rle-2014-0045.

— 2018. "Day Fines: Reviving the Idea and Reversing the (Costly) Punitive Trend." American Criminal Law Review 55(2): 333-72.

Krippner, Greta R. 2017. “Democracy of Credit: Ownership and the Politics of Credit Access in Late 
Twentieth-Century America." American Journal of Sociology 123(1): 1-47. DOI: https://doi.org/10 $.1086 / 692274$.

Krivo, Lauren J., and Robert L. Kaufman. 2004. "Housing and Wealth Inequality: Racial-Ethnic Differences in Home Equity in the United States." Demography 41(3): 585-605. DOI: https://doi.org/10.1353/dem.2004.0023.

Martin, Karin D. 2018. “Monetary Myopia: An Examination of Institutional Response to Revenue from Monetary Sanctions for Misdemeanors." Criminal Justice Policy Review 29(6-7): 630-62. DOI: https://doi.org/10.1177/0887403418761099.

Martin, Karin D., Bryan L. Sykes, Sarah K.S. Shannon, Frank Edwards, and Alexes Harris. 2018. “Monetary Sanctions: Legal Financial Obligations in US Systems of Justice." Annual Review of Criminology 1(1):471-95. DOI: https://doi.org /10.1146/annurev-criminol-032317-091915.

McKernan, Signe-Mary. 2013. "Less Than Equal: Racial Disparities in Wealth Accumulation." Washington, DC: Urban Institute.

Menendez, Matthew, Michael F. Crowley, LaurenBrooke Eisen, and Noah Atchison. 2019. The Steep Costs of Criminal Justice Fees and Fines. New York: Brennan Center for Justice.

Miller, Reuben Jonathan. 2014. “Devolving the Carceral State: Race, Prisoner Reentry, and the Micro-Politics of Urban Poverty Management." Punishment \& Society 16(3): 305-35. DOI: https://doi.org/10.1177/1462474514527487.

Nagrecha, Mitali. 2020. The Limits of Fairer Fines: Lessons from Germany. Cambridge, Mass.: Harvard Law School, Criminal Justice Policy Program.

National Research Council. 2014. The Growth of Incarceration in the United States: Exploring Causes and Consequences. Washington, DC: National Academies Press.

Office of Court Administration. 2019. Annual Statistical Report for the Texas Judiciary. Austin: State of Texas.

O'Malley, Pat. 2009. "Theorizing Fines." Punishment \& Society 11(1): 67-83. DOI: https://doi.org/10 $.1177 / 1462474508098133$.

Omi, Michael, and Howard Winant. 1994. Racial Formation in the United States: From the 1960s to the 1990s. New York: Psychology Press.

Pacewicz, Josh, and John N. Robinson III. 2020. “Pocketbook Policing: How Race Shapes Municipal Reliance on Punitive Fines and Fees in the
Chicago Suburbs." Socio-Economic Review. Published online October 2, 2010. mwaa029. DOI: https://doi.org/10.1093/ser/mwaa029.

Page, Joshua, and Joe Soss. 2017. "Criminal Justice Predation and Neoliberal Governance." In Rethinking Neoliberalism. New York: Routledge.

Pager, Devah. 2007. Marked: Race, Crime, and Finding Work in an Era of Mass Incarceration. Chicago: University of Chicago Press.

Pager, Devah, and Hana Shepherd. 2008. "The Sociology of Discrimination: Racial Discrimination in Employment, Housing, Credit, and Consumer Markets." Annual Review of Sociology 34(1): 181209. DOI: https://doi.org/10.1146/annurev.soc 33.040406.131740.

Pattillo, Mary, and Gabriela Kirk. 2021. “Layaway Freedom: Coercive Financialization in the Criminal Legal System." American Journal of Sociology 126(4): 889-930. DOI: https://doi.org/10.1086 $/ 712871$.

Pedulla, David S., and Devah Pager. 2019. "Race and Networks in the Job Search Process." American Sociological Review 84(6): 983-1012. DOI: https://doi.org/10.1177/0003122419883255.

Pettit, Becky, and Bruce Western. 2004. “Mass Imprisonment and the Life Course: Race and Class Inequality in U.S. Incarceration." American Sociological Review 69(2): 151-69. DOI: https://doi .org/10.1177/000312240406900201.

Piketty, Thomas, and Emmanuel Saez. 2014. “Inequality in the Long Run." Science 344(6186): 838-43. DOI: https://doi.org/10.1126/science .1251936 .

Quillian, Lincoln, Devah Pager, Ole Hexel, and Arnfinn H. Midtbøen. 2017. “Meta-Analysis of Field Experiments Shows No Change in Racial Discrimination in Hiring over Time." Proceedings of the National Academy of Sciences 114(41): 1087075. DOI: https://doi.org/10.1073/pnas.1706 255114.

Ray, Victor. 2019. "A Theory of Racialized Organizations." American Sociological Review. First published online January 25, 2019. DOI: https://doi .org/10.1177/0003122418822335.

Reskin, Barbara. 2012. “The Race Discrimination System." Annual Review of Sociology 38(1): 17-35.

Ross, Stephen L., and Margery Austin Turner. 2005. “Housing Discrimination in Metropolitan America: Explaining Changes between 1989 and 2000." Social Problems 52(2): 152-80. DOI: https://doi.org/10.1525/sp.2005.52.2.152. 
Rugh, Jacob S., and Douglas S. Massey. 2010. “Racial Segregation and the American Foreclosure Crisis." American Sociological Review 75(5): 62951. DOI: https://doi.org/10.1177/00031224 10380868.

Sanchez, Amairini, Michele Cadigan, Dayo AbelsSullivan, and Bryan L. Sykes. 2022. “Punishing Immigrants: The Consequences of Monetary Sanctions in the Crimmigration System." RSF: The Russell Sage Foundation Journal of the Social Sciences 8(2): 76-97. DOI: https://doi.org/10 .7758/RSF.2022.8.2.04.

Sewell, Abigail A. 2016. “The Racism-Race Reification Process: A Mesolevel Political Economic Framework for Understanding Racial Health Disparities." Sociology of Race and Ethnicity 2(4): 402-32. DOI: https://doi.org/10.1177/233 2649215626936.

Slavinski, llya, and Becky Pettit. 2021. "Proliferation of Punishment: The Centrality of Legal Fines and Fees in the Landscape of Contemporary Penology." Social Problems. First published online January 12,2021 . spaa077. DOI: https://doi.org/10 .1093/socpro/spaa077.

Soss, Joseph, Richard C. Fording, and Sanford F. Schram. 2011. Disciplining the Poor: Neoliberal Paternalism and the Persistent Power of Race. Chicago: University of Chicago Press.

Stewart, Robert, Brieanna Watters, Veronica Horowitz, Ryan P. Larson, Brian Sargent, and Christopher Uggen. 2022. “Native Americans and Monetary Sanctions." RSF: The Russell Sage Foundation Journal of the Social Sciences 8(2): 137-56. DOI: https://doi.org/10.7758/RSF .2022.8.2.07.

Sykes, Bryan L., Meghan Ballard, Andrea Giuffre, Rebecca Goodsell, Daniela Kaiser, Vicente Celestino Mata, and Justin Sola. 2022. “Robbing Peter to Pay Paul: Public Assistance, Monetary Sanctions, and Financial Double-Dealings in America." RSF: The Russell Sage Foundation Journal of the Social Sciences 8(1): 14878. DOI: https://doi.org/10.7758/RSF.2022 .8.1.07.

Thompson, Jeffrey P., and Gustavo Suarez. 2015. "Exploring the Racial Wealth Gap Using the Survey of Consumer Finances." SSRN scholarly pa- per no. 2665627. Rochester, N.Y.: Social Science Research Network.

Tonry, Michael. 2018. “Punishment and Human Dignity: Sentencing Principles for Twenty-FirstCentury America." Crime and Justice 47(1): 11957. DOI: https://doi.org/10.1086/696948.

Turner, Susan, and Judith Greene. 1999. “The FARE Probation Experiment: Implementation and Outcomes of Day Fines for Felony Offenders in Maricopa County." Justice System Journal 21(1): 1-21.

U.S. Census Bureau. 2019. “Median Household Income in the Past 12 Months (Table Series B19013)" 2015-2019 American Community Survey 5-year Estimates. Accessed August 10, 2021. https://data.census.gov/cedsci/table?q=income $\& g=0400000$ US48\%248600000\&d=ACS $\% 20$ 5-Year\%20Estimates\%20Detailed\%20 Tables\&tid=ACSDT5Y2019.B19013.

Wacquant, Loïc. 2009. Punishing the Poor: The Neoliberal Government of Social Insecurity. Durham, N.C.: Duke University Press Books.

Wakefield, Sara, and Christopher Uggen. 2010. “Incarceration and Stratification." Annual Review of Sociology 36(1): 387-406. DOI: https://doi.org /10.1146/annurev.soc.012809.102551.

Weaver, Vesla M., Andrew Papachristos, and Michael Zanger-Tishler. 2019. “The Great Decoupling: The Disconnection Between Criminal Offending and Experience of Arrest Across Two Cohorts." RSF: The Russell Sage Foundation Journal of the Social Sciences 5(1): 89-123. DOI: https://doi.org/10 .7758/RSF.2019.5.1.05.

Western, Bruce. 2006. Punishment and Inequality in America. New York: Russell Sage Foundation.

Whitman, James Q. 2003. Harsh Justice: Criminal Punishment and the Widening Divide Between America and Europe. Oxford: Oxford University Press.

—. 2009. "Equality in Criminal Law: Two Divergent Western Roads." Journal of Legal Analysis 1(1): 119-65.

Winterfield, Laura A., and Sally T. Hillsman. 1993. "The Staten Island Day-Fine Project." Washington: U.S. Department of Justice, National Institute of Justice. Accessed August 17, 2021. https://www.vera.org/publications/the-staten -island-day-fines-experiment. 